\title{
Analisis Penguasaan Kompetensi Pedagogik dan Profesional Mahasiswa Calon Guru Matematika
}

\author{
L. Linda \\ STKIP Syekh Manshur. Jalan Raya Labuan Km. 5 Kadulisung, Pandeglang, Banten 42253, Indonesia. \\ E-mail: linda90linda@gmail.com
}

Received: 20 May 2017; Revised:7 June 2017; Accepted: 10 June 2017

\begin{abstract}
Abstrak
Penelitian ini bertujuan untuk mendeskripsikan penguasaan kompetensi pedagogik dan profesional mahasiswa calon guru matematika dalam mata kuliah micro-teaching di Universitas Sultan Ageng Tirtayasa Provinsi Banten. Penelitian ini merupakan penelitian deskriptif. Subjek sebanyak 16 mahasiswa yang dipilih secara acak dari 72 mahasiswa jurusan pendidikan matematika, Universitas Sultan Ageng Tirtayasa Provinsi Banten tahun akademik 2014/2015. Objek penelitian adalah kompetensi pedagogik dan profesional mahasiswa calon guru matematika dalam mata kuliah microteaching di Universitas Sultan Ageng Tirtayasa Provinsi Banten. Data hasil penelitian dianalisis dengan melihat kriteria penguasaan kompetensi pedagogik dan profesional. Hasil penelitian menunjukkan bahwa penguasaan kompetensi pedagogik mahasiswa calon guru matematika dalam mata kuliah micro-teaching di Universitas Sultan Ageng Tirtayasa Provinsi Banten, berada pada kriteria baik. Penguasaan kompetensi profesional mahasiswa calon guru matematika Universitas Sultan Ageng Tirtayasa Provinsi Banten, berada pada kriteria kurang.
\end{abstract}

Kata Kunci: kompetensi pedagogik, kompetensi profesional, mahasiswa calon guru, micro-teaching

\section{An Analysis of Pedagogical and Professional Competence Mastery of Prospective Mathematics Teacher}

\begin{abstract}
The study aims to describe the mastery of the pedagogical competence and the professional competence of prospective mathematics teacher in micro-teaching courses at the University of Sultan Ageng Tirtayasa in Banten Province. The study was descriptive research. The subjects were 16 prospective mathematics teacher who were randomly selected from 72 students of the Department of Mathematics Education, University of Sultan Ageng Tirtayasa Banten, in the academic year of 2014/2015. The objectives of this research were the pedagogical and professional competence of prospective mathematics teacher. The data were analyzed by observing the criteria for pedagogical competence mastery and professional competence mastery. The results of study show that the pedagogical competence mastery of the prospective mathematics teacher in the subjects of microteaching at the University of Sultan Ageng Tirtayasa in Banten Province was in the good criterion. The mastery of the professional competence of prospective mathematics teacher in the same subjects was not in a less criterion.
\end{abstract}

Keywords: pedagogical competence, professional competence, prospective mathematics teacher, micro-teaching

How to Cite: Linda, L. (2017). Analisis penguasaan kompetensi pedagogik dan profesional mahasiswa calon guru matematika dalam mata kuliah micro-teaching. PYTHAGORAS: Jurnal Pendidikan Matematika, 12(1), 6575. doi:http://dx.doi.org/10.21831/pg.v12i1.14053

Permalink/DOI: http://dx.doi.org/10.21831/pg.v12i1.14053 


\section{PENDAHULUAN}

Upaya perbaikan mutu dan kualitas pendidikan di Indonesia terus dilakukan oleh pemerintah dari tahun ke tahun. Perbaikan tersebut dilakukan seiring dengan hasil evaluasi yang dilakukan dari tahun ke tahun. Perbaikan tersebut salah satunya terlihat dari perubahan kurikulum yang diberlakukan, khususnya pada pendidikan dasar dan menengah. Perubahan kurikulum adalah salah satu perwujudan dari pasal 11 UU No 20 tahun 2003 tentang Sistem Pendidikan Nasional bahwa pemerintah memiliki kewajiban untuk menjamin terselenggaranya pendidikan yang bermutu bagi setiap warga negara tanpa diskriminasi. Penyelenggaraan Pendidikan yang bermutu ini diharapkan akan menghasilkan lulusan yang memiliki kompetensi yang siap untuk menghadapi persaingan.

Kompetensi yang dibutuhkan peserta didik untuk menghadapi persaingan tidak dapat diperoleh dengan cara yang instan. Perlu usaha untuk membekali mereka dengan kompetensi itu. Salah satu mata pelajaran yang memiliki peran penting dan membantu siswa dalam memahami berbagai konsep dalam mata pelajaran lainnya adalah matematika (Muijs \& Reynold, 2011, p.256). Oleh sebab itu, matematika menjadi salah satu mata pelajaran wajib sejak sekolah dasar hingga menengah.

Salah satu cara untuk mengetahui capaian peserta didik dalam belajar matematika dapat mengacu pada hasil belajar mereka yang tercermin dari hasil Ujian Nasional (UN). Akan tetapi hasil UN khususnya matematika dari tahun ke tahun masih belum maksimal. Belum maksimalnya hasil belajar peserta didik tersebut menjadi salah satu indikator rendahnya kualitas pendidikan. Oleh karena itu, hasil tersebut sudah seharusnya menjadi bahan evaluasi bagi semua pihak, baik dari pemerintah sebagai penentu kebijakan, hingga bagi guru sebagai pelaksana di lapangan.

Guru merupakan salah satu faktor pendukung bahkan bisa dikatakan faktor utama. Hal ini didukung oleh pendapat Rusman (2012, p.238) yang mengemukakan bahwa professionnalitas seorang guru merupakan salah satu faktor penentu kualitas pendidikan. Karena pentingnya peran guru, maka pada pasal 8 Undang-Undang Nomor 14 Tahun 2005 tentang guru dan dosen diatur mengenai keharusan seorang guru untuk memiliki kualifikasi akademik, kompetensi, sertifikat pendidik, sehat jasmani dan rohani, serta memiliki kemampuan untuk mewujudkan tujuan pendidikan nasional (Republik Indonesia, 2005a).

Ketetapan perundangan tersebut mempertegas bahwa guru tidak hanya dituntut menguasai pengetahuan sesuai bidangnya, tetapi juga harus memiliki kriteria maupun kompetensi lainnya sehingga mendukung tercapainya tujuan pendidikan nasional. Hal ini diperkuat oleh Sedgwick (2008, p.7); Shukla (2014, p.44); dan Vijila (2015, p.1151) bahwa kompetensi tersebut tidak hanya membutuhkan berkaitan dengan pengetahuan, tetapi juga kemampuan untuk mengimplementasikan pengetahuan itu dalam menjalankan tugas.

Kompetensi guru merupakan kemampuan dalam hal pengetahuan, pengetahuan ilmiah, keterampilan, sikap, dan pengembangan diri yang harus dikuasai dan dimiliki oleh guru dalam melaksanakan tugasnya. Hal tersebut sesuai dengan sejumlah pendapat yang mengemukakan bahwa kompetensi merujuk pada pengetahuan, keterampilan, sikap, maupun kemampuan (Boyatzis, 2008, p.6; Varvel, 2007, p.3) yang diperlukan agar dapat melaksanakan tugas dengan baik. Kompetensi guru di Indonesia telah disebutkan dalam Peraturan Pemerintah nomor 19 Tahun 2005 tentang Standar Nasional Pendidikan yaitu, kompetensi pedagogik, kompetensi kepribadian, kompetensi profesional, dan kompetensi sosial (Republik Indonesia, 2005b).

Pedagogik berhubungan seni dan ilmu mengajar (Arends, 2012, p.7). Kompetensi pedagogik merupakan kompetensi guru dalam mengajar dan mengelola pembelajaran, yang meliputi pemahaman terhadap peserta didik, perancangan dan pelaksanaan pembelajaran, evaluasi hasil belajar, dan pengembangan peserta didik untuk mengaktualisasikan berbagai potensi yang dimilikinya (Mulyasa, 2013, p.42; Chatib, 2011, p.28). Selain itu, Cooper (Syahrudin, et al., 2013, p.214) menyatakan bahwa kompetensi pedagogik mengacu pada kinerja, pengetahuan dan keterampilan dalam mengajar dan belajar sehingga mencakup kemampuan guru untuk mengelola proses belajar mengajar, proses dari perencanaan ke tahap evaluasi.

Kompetensi kepribadian merupakan kompetensi yang berkaitan dengan sikap simpati, empati, terbuka, berwibawa, bertanggung jawab, sesuai dengan norma agama, hukum, sosial, kebudayaan dan mampu menilai diri sendiri dalam hal bersikap (Sanjaya, 2013, p.20; Mulyasa, 2013, p.69; UU RI No. 14 Tahun 2005 
pasal 10 ayat 1). Artinya, kompetensi kepribadian ditunjukkan dari cara guru dalam bertindak dan berperilaku selama baik dalam melaksanakan tugasnya di sekolah maupun di luar sekolah.

Kompetensi sosial adalah kemampuan seseorang untuk berhubungan dengan orang lain, terlibat dengan orang lain, dan kemampuan mengatasi emosi saat berhubungan dengan orang lain (Sit, 2012, p.98). Adapun kompetensi sosial pada guru adalah kemampuan seorang guru untuk mengkomunikasikan baik dalam bentuk lisan, tulisan, atau bahasa isyarat, hal-hal yang berkaitan dengan pembelajaran, perkembangan peserta didik, dengan orang tua wali murid, masyarakat sekolah dan peserta didik ketika proses belajar di kelas (Legkauskas, Kapalaite, \& Magelinskaite, 2014, p.2936; Mulyasa, 2013, p.71; Sanjaya, 2013, p.20; UU RI No. 14 Th 2005 pasal 10 ayat 1).

Selanjutnya, kompetensi yang harus dimiliki guru adalah kompetensi profesional. Kata profesional dapat diartikan sebagai perilaku, tujuan, atau kualitas yang menjadikan ciri atau menandai suatu pekerjaan, atau seseorang yang ahli di bidang tertentu (Collins dan O'brien, 2011, p.372). Kompetensi profesional merupakan kemampuan seorang guru dalam penguasaan materi pembelajaran secara luas dan mendalam sesuai standar isi program satuan pendidikan, mata pelajaran, kelompok mata pelajaran yang diampunya dan konsep-konsep serta metode disiplin keilmuan, teknologi yang relevan yang secara konseptual menaungi program satuan pendidikan, mata pelajaran, dan kelompok mata pelajaran yang diampu (Mulyasa, 2013, p.42; Chatib, 2011, p.29; Belousa \& Uzulina, 2012, p.167).

Guru yang baik mampu mengelola proses belajar mengajar di kelas dengan baik serta mampu menguasai materi yang akan diajarkan. Apabila guru dapat mengelola kelas dan menguasai materi dengan baik, maka peserta didik akan merasa nyaman dan semangat dalam belajar. Sering ditemukan keluhan peserta didik mengenai guru matematika yang tidak mengasyikkan ketika mengajar di kelas dan penguasaan materi yang kurang. Dengan demikian banyak peserta didik yang menganggap bahwa pelajaran matematika adalah pelajaran yang sulit (Muijs dan Reynolds, 2011, p.255).

Kurangnya kompetensi sebagian guru matematika dalam mengajar dapat diketahui dari hasil Uji Kompetensi Guru (UKG) se-Indonesia pada tahun 2012. Kompetensi yang diujikan pada Uji Kompetensi Guru (UKG) adalah kompetensi pedagogik dan profesional. Berdasarkan data rata-rata hasil UKG kompetensi pedagogik dan profesional guru matematika SMP dan SMA se-Indonesia Tahun 2012 pada Tabel 1. Diketahui bahwa hasil UKG tersebut dari satu Provinsi ke Provinsi lain di Indonesia hasilnya bervariasi. Rata-rata hasil UKG guru matematika di Provinsi Banten pada tahun 2012 dapat dilihat pada Tabel 1.

Tabel. 1 Rata-Rata Nilai UKG Guru matematika SMP dan SMA Provinsi Banten Tahun 2012

\begin{tabular}{cccc}
\hline \multicolumn{2}{c}{ Kompetensi Pedagogik } & \multicolumn{2}{c}{ Kompetensi Profesional } \\
\hline SMP & SMA & SMP & SMA \\
\hline 46,99 & 42,31 & 60,05 & 45,03 \\
\hline
\end{tabular}

Sumber:http://ukg.kemdikbud.go.id/info/?id=grafikp elaksanaan\&jenis

Berdasarkan hasil UKG se-Indonesia, rata-rata nilai guru matematika di Provinsi Banten untuk kompetensi pedagogik dan profesional sudah melewati rata-rata hasil UKG Se-Indonesia. Walaupun demikian jika dilihat lebih detail lagi, rata-rata hasil UKG setiap daerah tingkat II di Provinsi Banten cukup beragam. Rata-rata hasil UKG guru matematika untuk kompetensi pedagogik dan profesional tingkat SMP dan SMA Provinsi Banten dapat dilihat pada Tabel 2.

Tabel 2. Rata-Rata Nilai UKG Guru Matematika SMP dan SMA Provinsi Banten

\begin{tabular}{lcccc}
\hline \multirow{1}{*}{\multicolumn{1}{c}{ Daerah }} & \multicolumn{3}{c}{ Kompetensi yang Dinilai } \\
\cline { 2 - 5 } & \multicolumn{3}{c}{ Pedagogik } & \multicolumn{2}{c}{ Profesional } \\
\cline { 2 - 5 } & SMP & SMA & SMP & SMA \\
\hline Kota Tangerang & 47,02 & 42,19 & 61,77 & 42,71 \\
Kab. Tangerang & 43,97 & 37,68 & 57,68 & 40,66 \\
Kab. Pandeglang & 45,25 & 43,48 & 53,59 & 46,32 \\
Kab. Lebak & 45,68 & 46,99 & 58,12 & 46,36 \\
Kota Tangerang & 47,01 & 41,90 & 59,78 & 51,42 \\
Selatan & 49,53 & 41,76 & 58,57 & 42,36 \\
Kab. Serang & 52,93 & 44,62 & 68,51 & 51,47 \\
Kota Serang & 48,48 & 46,25 & 66,36 & 45,69 \\
Kota Cilegon &
\end{tabular}

Sumber:http://ukg.kemdikbud.go.id/info/?id=gra fikpelaksanaan\&jenis

Rata-rata hasil UKG guru matematika untuk kompetensi pedagogik tingkat SMP di Provinsi Banten adalah 47 dan kompetensi profesional adalah 61. Pada Tabel 2, dapat dilihat bahwa rata-rata hasil kompetensi peda-gogik dan profesional pada tingkat SMP hasilnya bervariasi. Hasil yang bervariasi ini, terda-pat beberapa daerah yang rata-rata hasil UKG-nya kurang dari rata-rata UKG se-Indonesia. Selain itu, terdapat beberapa daerah yang hasil UKG guru matematika SMAnya kurang dari rata-rata se-Indonesia. 
Perguruan tinggi di Provinsi Banten yang menyelenggarakan jurusan Pendidikan Matematika yaitu Universitas Sultan Ageng Tirtayasa (UNTIRTA, Perguruan Tinggi Negeri), Universitas Muhamadiyah Tangerang (UMT, Perguruan Tinggi Swasta), dan Universitas Matlahul Anwar (UNMA, Perguruan Tinggi Swasta). Universitas Sultan Ageng Tirtayasa merupakan perguruan tinggi negeri yang diharapkan dapat menghasilkan lulusan guru yang baik dan profesional. Namun, UNTIRTA yang baru 14 tahun berdiri menjadi universitas negeri memerlukan banyak masukan untuk bisa meningkatkan kualitas proses belajar mengajar yang lebih baik lagi.

Untuk mengetahui kualitas mahasiswa calon guru matematika di UNTIRTA dapat diketahui dari kurikulumnya. Mahasiswa UNTIRTA mendapatkan mata kuliah strategi belajar mengajar, matematika sekolah, evaluasi proses dan hasil pembelajaran matematika, profesi pendidik dan tenaga kependidikan, psikologi pendidikan dan bimbingan peserta didik, perencanaan pembelajaran matematika, dan pengelolaan pendidikan. Pada semester enam, mahasiswa Jurusan Pendidikan Matematika UNTIRTA mendapatkan mata kuliah microteaching atau dalam kulikulum UNTIRTA sekarang disebut sebagai mata kuliah Pembinaan Kompetensi Mengajar (PKM).

Mata kuliah micro-teaching (pembelajaran mikro) sebagai mata kuliah praktik mengajar, dapat diartikan sebagai cara latihan keterampilan keguruan atau praktik mengajar dalam lingkup kecil (Asril, 2013, p.43). Mata kuliah microteaching termasuk bagian dari sarana untuk melatih mahasiswa calon guru mengajar di kelas dengan kondisi dan waktu mengajar yang disederhanakan. Menurut Allen (Ralph, 2014, p.1) Micro-teaching awalnya diciptakan pada awal tahun 1960 di Sanfrord University sebagai jenis kegiatan simulasi skala kecil untuk membantu calon guru mengajar. micro-teaching adalah teknik pelatihan guru yang pertama kali dikembangkan oleh Dwight W. Allen, dan rekan-rekannya di Stanford University pada tahun 1963 (Ping, 2013, p.165). Micro-teaching bertujuan untuk meningkatkan keterampilan pedagogik calon guru, mempersiapkan calon guru menghadapi praktik mengajar di lapangan (sekolah) atau pekerjaan mengajar ketika lulus, mengajar di depan kelas dengan memiliki pengetahuan, keterampilan dan sikap sebagai guru profesional sehingga menumbuhkan rasa percaya diri (Kilic, 2010, p.83; UNY, 2011, p.2; Strait, 2013, p.3; Sukirman, 2012, p.34).

Mahasiswa jurusan Pendidikan Matematika di UNTIRTA pada mata kuliah microteaching mendapatkan kesempatan praktik mengajar di kelas hanya satu kali. Praktik mengajar satu kali ini besar kemungkinan tidak cukup memadai untuk menyiapkan mahasiswa menjadi guru yang profesional. Sebagai perbandingan di Daerah Istimewa Yogyakarta (DIY) terdapat tiga universitas yang praktik mengajarnya lebih dari satu kali, yakni Universitas Islam Negeri Sunan Kali Jaga, Yogyakarta (minimal tiga kali praktik), Universitas Negeri Yogyakarta (minimal delapan kali praktik), dan Universitas Sarjanawiyata Taman Siswa, Yogyakarta (keterampilan dasar mengajar terbatas empat kali, dan keterampilan dasar mengajar terpadu empat kali).

Berdasarkan uraian tersebut, peneliti bermaksud untuk mengetahui kompetensi yang dimiliki oleh mahasiswa calon guru matematika di UNTIRTA. Dengan mengacu pada kompetensi yang diujikan dalam UKG, maka penelitian ini juga difokuskan pada kompetensi pedagogik dan profesional. Keempat kompetensi guru akan lebih banyak terlihat ketika mahasiswa calon guru matematika terjun langsung mengajar di sekolah yaitu pada saat Program Pengalaman Lapangan (PPL). Dengan demikian, tujuan pada penelitian ini adalah mendeskripsikan penguasaan kompetensi pedagogik dan profesional mahasiswa calon guru matematika dalam mata kuliah micro-teaching di Universitas Sultan Ageng Tirtayasa Provinsi Banten.

\section{METODE}

Jenis penelitian adalah deskriptif. Data yang dideskripsikan adalah kompetensi pedagogik dan profesional dari mahasiswa Universitas Sultan Ageng Tirtayasa yang mengambil mata kuliah micro-teaching pada semester enam tahun ajaran 2014/2015. Tempat penelitian dilaksanakan di Jurusan Pendidikan Matematika Universitas Sultan Ageng Tirtayasa Provinsi Banten. Waktu pelaksanaan penelitian dimulai pada tanggal 02 April 2015 sampai dengan 04 Juni 2015.

Subjek penelitian ini adalah 16 mahasiswa Jurusan Pendidikan Matematika semester enam yang dipilih secara acak dari 72 mahasiswa Jurusan Pendidikan Matematika Universitas Sultan Ageng Tirtayasa Provinsi Banten tahun ajaran 2014/2015. Objek penelitian ini adalah kompetensi pedagogik dan kompetensi 
profesional mahasiswa calon guru matematika dalam mata kuliah micro-teaching di Universitas Sultan Ageng Tirtayasa Provinsi Banten.

Hasil pengocokan dalam menentukan subjek penelitian diberikan kode untuk menjaga identitas mahasiswa yang diteliti. Enam belas mahasiswa yang menjadi subjek penelitian diberikan kebebasan untuk memilih materi pembelajaran yang akan dipraktikan dalam mata kuliah micro-teaching. Mahasiswa dalam mata kuliah micro-teaching diberikan kebebasan memilih materi dari kelas VII sampai kelas XI untuk ditampilkan. Masing-masing mahasiswa tampil satu kali dalam praktik micro-teaching.

Data kompetensi pedagogik dikumpulkan dengan menggunakan teknik observasi. Observasi dilakukan oleh dua (2) orang saat mahasiswa calon guru yang menjadi subjek penelitian melakukan praktik micro-teaching. Sementara itu, data mengenai kompetensi profesional diperoleh dengan memberikan tes di akhir penelitian. Pelaksanaan tes dilakukan dalam dua sesi, yaitu sesi ke-1 tes kompetensi bagian 1 dan sesi ke-2 tes kompetensi bagian 2.

Instrumen yang digunakan untuk mengumpulkan data pada penelitian ini adalah non tes dan tes. Instrumen non tes berupa lembar observasi yang terdiri atas 33 aspek yang diamati. Aspek tersebut berkaitan dengan penguasaan kompetensi pedagogik. Lembar observasi ini digunakan oleh observer untuk menilai subjek ketika praktik micro-teaching.

Pada lembar observasi diberi tanda ceklis $(\sqrt{ })$ pada pilihan penilaian, sesuai dengan keadaan subjek penelitian ketika praktik di depan kelas pada mata kuliah micro-teaching. Penentuan indikator pada lembar observasi praktik pembelajaran micro-teaching pada penelitian ini diadaptasi dari penilaian PPG dan PLPG. Lembar observasi berbentuk daftar pilihan (cheklist) yang terdiri atas beberapa butir pernyataan aspek yang diamati untuk mengetahui penguasaan kompetensi pedagogik mahasiswa calon guru matematika UNTIRTA Provinsi Banten.

Model penilaian yang digunakan adalah skala likert dengan lima pilihan penilaian, Sangat Baik (Sb), Baik (B), Kurang Baik (Kb), Tidak Baik (Tb), dan Sangat Tidak Baik (Stb). Pensekoran butir pada lembar observasi dilakukan dengan memberi skor 5 untuk respons Sangat Baik (Sb), 4 untuk Baik (B), 3 untuk Kurang Baik (Kb), 2 untuk Tidak Baik (Tb), dan 1 untuk Sangat Tidak Baik (Stb). Skor maksimal dalam lembar obervasi pembelajaran mikro (micro-teaching) adalah 165 .

Instrumen tes yaitu berupa soal uraian yang diberikan untuk mengukur kompetensi profesional. Materi yang diteskan adalah materi yang daya serap Ujian Nasionalnya rendah, pada jenjang SMP, SMA, dan SMK tahun ajaran 2009/2010, 2010/2011, 2011/2012, dan 2012/ 2013. Materi pada daya serap yang rendah ini dijadikan indikator untuk membuat soal uraian. Soal uraian ini terdiri atas 15 soal uraian yang dibagi dua set, yaitu tes kompetensi profesional bagian 1 pada sesi 1 dengan 7 soal uraian dan tes kompetensi profesional bagian 2 pada sesi 2 dengan 8 soal uraian. Skor pada setiap butir soal berbeda-beda, skor terbesar pada soal uraian ini adalah 20 dan total skor keseluruhan adalah 150 . Hasil dari tes kompetensi profesional tidak dikaitkan dengan materi ajar yang dipraktikkan oleh mahasiswa calon guru. Jadi, tes kompetensi profesional hanya mengukur penguasaan kompetensi profesional mahasiswa calon guru matematika Universitas Sultan Ageng Tirtayasa Provinsi Banten secara umum.

Peneliti memulai mengambil data mahasiswa dalam peraktik micro-teaching pada tanggal 02 April 2015. Pada pelaksanaannya, dari pertemuan ke 6 sampai dengan pertemuan ke 13. Terdapat 16 mahasiswa yang menjadi subjek dalam penelitian ini, masing-masing berasal dari 10 mahasiswa dari kelas A dan 6 mahasiswa dari kelas B. Perbedaan pengambilan subjek yang berbeda pada kelas A dan B dikarenakan jumlah mahasiswa di kelas B lebih sedikit dari pada jumlah mahasiswa di kelas A.

Mahasiswa yang praktik dalam satu pertemuan ditargetkan sebanyak 3 orang. Namun faktanya, tidak semua pertemuan disetiap kelas terdapat 3 mahasiswa yang melakukan praktik micro-teaching. Apabila waktu memungkinkan, 3 atau 4 mahasiswa dapat melakukan praktik pembelajaran mikro, apabila tidak memungkinkan maka hanya 2 mahasiswa saja yang praktik pembelajaran mikro.

Data kompetensi pedagogik diperoleh dari hasil observasi selama enam kali pertemuan dalam praktik pembelajaran mikro. Setelah praktik pembelajaran dilaksanakan dan data dari 16 dari subjek penelitian telah terkumpul, peneliti melakukan pengambilan data kompetensi profesional mahasiswa calon guru matematika dengan memberikan soal uraian. Pada pertemuan ke-tujuh yaitu (03 Juni 2015) dilaksanakan tes kompetensi profesional bagian 1 dan perte- 
muan ke-delapan (04 Juni 2015) dilaksanakan tes kompetensi profesional bagian 2 .

Tabel 3. Kriteria Penguasaan Kompetensi Pedagogik Mahasiswa Calon Guru Matematika

\begin{tabular}{cc}
\hline Interval Skor & Kriteria \\
\hline$X>139$ & Sangat Baik \\
$112<X \leq 138,6$ & Baik \\
$85,8<X \leq 112,2$ & Cukup \\
$59,4<X \leq 85,8$ & Kurang \\
$X \leq 59,4$ & Sangat Kurang \\
\hline
\end{tabular}

Analisis data kompetensi pedagogik didasarkan pada 33 butir yang mengukur aspekaspek kompetensi tersebut. Skor minimum idealnya adalah 33, skor maksimumnya adalah 165. Berdasarkan hal tersebut dapat ditentukan rerata ideal $(\bar{X})$ dan simpangan baku idealnya $\left(s b_{i}\right)$ yaitu: rerata ideal $(\bar{X})=(165+33) / 2=99$ dan simpangan baku ideal $\left(s b_{i}\right)(165-33) / 6=$ 22. Setelah memperoleh data mengenai kompetensi pedagogik mahasiswa calon guru matematika UNTIRTA, total skor kompetensi pedagogik mahasiswa calon guru matematika dilihat kriterianya berdasarkan Widoyoko (2009, p.238), dapat dilihat pada Tabel 3.

Sementara itu, analisis data untuk kompetensi profesional dilakukan terhadap 15 butir soal yang terdiri atas 7 soal uraian untuk sesi pertama dan 8 soal uraian untuk sesi kedua. Skor minimum idealnya adalah 0 dan skor maksimum idealnya adalah 150, dari skor tersebut diketahui rerata idealnya yaitu $(150+$ $0) / 2=75$ dan simpangan baku idealnya yaitu $(150-0) / 6=25$. Selanjutnya rerata dan simpangan baku ideal yang sudah diketahui dilihat kriterianya berdasarkan Tabel 4.

Tabel 4. Kriteria Penguasaan Kompetensi Profesional Mahasiswa Calon Guru Matematika

\begin{tabular}{cc}
\hline Interval Skor & Kriteria \\
\hline$X>120$ & Sangat Baik \\
$90<X \leq 120$ & Baik \\
$60<X \leq 90$ & Cukup \\
$30<X \leq 60$ & Kurang \\
$X \leq 30$ & Sangat Kurang \\
\hline
\end{tabular}

Setelah mengetahui hasil penilaian kompetensi pedagogik dan kompetensi profesional dari 16 mahasiswa yang diteliti, selanjutnya dihitung persentase yang masuk kriteria sangat baik, baik, cukup, kurang, dan sangat kurang. Kompetensi pedagogik dan kompetensi profesional mahasiswa calon guru matematika Universitas Sultan Ageng Tirtayasa Provinsi Banten, dikatakan baik jika lebih dari $75 \%$ mahasiswa yang mempunyai kriteria minimal baik. Sebaliknya, jika kriteria minimal baik kurang dari atau sama dengan $75 \%$, maka dapat disimpulkan bahwa secara keseluruhan dari 16 mahasiswa yang diteliti dapat dianggap mempunyai penguasaan kompetensi pedagogik dan kompetensi profesional yang kurang.

\section{HASIL DAN PEMBAHASAN}

\section{Kompetensi Pedagogik}

Data kompetensi pedagogik yang diperoleh dari hasil observasi penilaian praktik micro-teaching oleh 2 observer memberikan informasi mengenai rata-rata kompetensi pedagogik subjek penelitian. Adapun hasil penilaian kompetensi pedagogik mahasiswa calon guru matematika Universitas Sultan Ageng Tirtayasa Provinsi Banten dapat dilihat pada Tabel 6.

Tabel 5. Hasil Penilaian Kompetensi Pedagogik Mahasiswa Calon Guru Matematika

\begin{tabular}{cc}
\hline Deskripsi & Hasil Penilaian \\
\hline Rata-rata & 121,9 \\
Standar Deviasi & 7,9 \\
Skor Maksimum Ideal & 165,0 \\
Skor Minimum Ideal & 33,0
\end{tabular}

Hasil analisis deskriptif tersebut menunjukkan bahwa rata-rata kompetensi pedagogik mahasiswa calon guru matematika adalah 121,906 . Hal ini menunjukkan bahwa rata-rata kompetensi pedagogik mahasiswa calon guru matematika UNTIRTA berada pada kriteria baik. Sementara itu, hasil observasi praktik pembelajaran mikro (micro teaching) terhadap 16 orang subjek penelitian (Tabel 6) menunjukkan bahwa penguasaan kompetensi pedagogik 15 mahasiswa berada dikriteria baik dan 1 mahasiswa yang berkriteria cukup.

Tabel 6. Hasil Lembar Observasi Praktik Pembelajaran Mikro (Micro Teaching)

\begin{tabular}{ccc}
\hline Mahasiswa & Skor & Kriteria \\
\hline A1 & 116 & Baik \\
A2 & 121 & Baik \\
A3 & 122,5 & Baik \\
A4 & 120,5 & Baik \\
A5 & 125 & Baik \\
A6 & 127 & Baik \\
A7 & 114,5 & Baik \\
A8 & 136 & Baik \\
A9 & 132 & Baik \\
A10 & 116 & Baik \\
A11 & 104 & Cukup \\
A12 & 122 & Baik \\
A13 & 115 & Baik \\
A14 & 128,5 & Baik \\
A15 & 122,5 & Baik \\
A16 & 129,5 & Baik \\
\hline
\end{tabular}


Hasil penilaian tersebut menunjukkan bahwa 94\% mahasiswa calon guru matematika Universitas Sultan Ageng Tirtayasa yang menjadi subjek penelitian telah memiliki kompetensi pedagogik dengan kriteria minimal baik. Oleh karena itu, dapat disimpulkan bahwa mahasiswa calon guru matematika Universitas Sultan Ageng Tirtayasa telah memiliki penguasaan terhadap kompetensi pedagogik.

Subjek yang mendapatkan kriteria baik dalam penguasaan kompetensi pedagogik, ratarata pada saat pelaksanaan praktik microteaching menyiapkan peralatan pembelajarannya sangat baik dan sudah siap. Ketika pelaksanaan pembelajaran berlangsung, subjek berkriteria baik ini membawakannya dengan percaya diri, meyakinkan dalam menyampaikan materi, menyenangkan, dan interaktif dengan peserta didik (mahasiswa yang berperan sebagai peserta didik). Subjek berkriteria baik dalam hal pembuatan Rencana Pelaksanaan Pembelajaran (RPP) sudah baik. Pembuatan RPP yang baik dapat mempengaruhi penampilan yang baik ketika praktik. Sesuai dengan pendapat Salirawati (2011, p.4) yang menyatakan pentingnya persiapan dan perencanaan pembelajaran pada seorang pendidik. Apabila seorang pendidik tidak menguasai cara-cara persiapan dan perencanaan pembelajaran yang baik, sudah dapat dipastikan bahwa pembelajaran yang dilakukan tidak akan berhasil secara optimal.

RPP disusun agar mahasiswa calon guru dalam melaksanakan pembelajaran dengan baik. Melalui RPP, mahasiswa calon guru dapat merencanakan berbagai metode atau model pembelajaran baru sesuai dengan karakteristik materi yang akan disampaikan dan karakter peserta didik. Hal ini dikarenakan dalam RPP terkandung berbagai perencanaan, mulai dari tujuan pembelajaran yang akan dicapai, metode pembelajaran yang akan diterapkan, apersepsi yang akan dilakukan di awal mengajar, sampai pada langkah-langkah pembelajaran dan penilaian yang akan dilakukan.

Pada saat praktik micro-teaching di kelas, subjek berkriteria baik rata-rata menggunakan alat peraga. Penggunaan alat peraga tersebut memberikan nilai tambah dalam proses pelaksanaan pembelajaran. Alat peraga disiapkan tidak hanya untuk subjek sendiri tetapi juga disediakan untuk peserta didik yang membentuk kelompok belajar, jadi setiap kelompok belajar mendapatkan alat peraga. Selain penggunaan alat peraga, pembelajaran yang berlangsung dengan diskusi atau investigasi kelompok juga menambah kemenarikan pembelajaran. Ratarata subjek yang berkriteria baik pada saat memberikan arahan dan menyampaikan materi kepada peserta didik dilakukan dengan cara tidak monoton. Terdapat keseruan dalam praktik mengajar pada subjek yang berkriteria baik sehingga peserta didik antusias mengikuti pembelajaran. Hal tersebut sesuai dengan hasil-hasil penelitian terdahulu yang antara lain menyimpulkan bahwa penggunaan alat peraga dan melibatkan penyelidikan kelompok lebih efektif ditinjau dari apresiasi peserta didik dan prestasi belajar siswa dibandingkan dengan penggunaan alat peraga namun tanpa membuat kelompok (Sasongko, 2014, p.136). Hasil tersebut diperkuat pula oleh temuan Yulistiyarini \& Mahmudi (2015, p.164) bahwa penggunaan alat peraga tidak hanya mengembangkan kemampuan siswa pada ranah pengetahuan, tetapi juga mengembangkan sikap dan keterampilan siswa. Oleh karena itu, pembelajaran yang dilakukan oleh subjek (mahasiswa calon guru) dengan memanfaatkan alat peraga dengan desain pembelajaran berkelompok membuat menghasilkan pembelajaran lebih menyenangkan.

Subjek dengan kriteria baik menyampaikan materi sangat ekspresif dan menyenangkan. Suasana yang ceria dan menyenangkan, membuat mahasiswa yang berperan sebagai peserta didik merasa senang dan menanggapi pembelajaran dengan sangat aktif. Contohnya, ketika praktik pembelajaran di kelas terdapat subjek yang menutup pempelajaran dengan bernyanyi, ditengah-tengah pembelajaran diselingi dengan humor, mengajar dengan gaya gaul, dan lain sebagainya.

Selain faktor-faktor yang telah disebutkan tadi, terdapat faktor lainnya yang membuat subjek mendapatkan kriteria baik yaitu peserta didik yang dihadapi adalah temannya sendiri sehingga dapat bekerjasama ketika praktik mengajar. Oleh karena itu, subjek yang praktik dapat mudah mengarahkan peserta didik dalam proses praktik pembelajaran di kelas microteaching. Dibandingkan dengan praktik mengajar di sekolah yaitu menghadapi peserta didik secara langsung dengan tingkah yang beragam mengakibatkan pengendalian peserta didiknya sukar.

Sebaliknya subjek yang berkriteria cukup, rata-rata persiapannya kurang baik. Terlihat dari pembuatan Rencana Pelaksanaan Pembelajaran (RPP) yang kurang baik. Metode yang digunakan tidak efektif pada pelaksaan praktik pembelajarannya. Subjek berkriteria cukup menyam- 
paikan materinya kurang percaya diri sehingga kurang meyakinkan. Menyediakan alat peraga untuk dirinya sendiri, peserta didik tidak diberikan alat peraga, dengan demikian proses pembelajarannya tidak melibatkan peserta didik untuk berperan aktif.

Pada subjek berkriteria cukup, kurang dalam hal pengelolaan kelas (pedagogik). kompetensi pedagogik harus dikuasai oleh calon guru dan guru. Sebagaimana dijelaskan oleh Fujita H. et al (2004, p.115) pedagogik dirancang untuk membantu mahasiswa calon guru membuat konstruksi dan mengembangkannya, serta untuk mengembangkan pemahaman konsep melalui proses belajar mengajar di kelas. Oleh karena itu kompetensi pedagogik sangat penting harus dikuasai oleh seorang calon guru dan guru.

Sebagaimana yang telah disebutkan pada hasil penelitian bahwa penguasaan kompetensi pedagogik mahasiswa calon guru dalam mata kuliah micro-teaching terkategori baik. Hasil ini menunjukkan bahwa micro-teaching adalah salah satu sarana untuk mempersiapkan mahasiswa calon guru untuk menjadi guru di sekolah dan cara pelatihan pedagogik yang efektif untuk kompetensi mengajar. Hasil ini sejalan dengan hasil dari penelitian Ralph (2014) yang menyatakan bahwa calon guru mengakui bahwa microteaching merupakan cara pelatihan pedagogik yang efektif untuk meningkatkan kompetensi mengajar dan kepercayaan diri serta bermanfaat bagi mereka.

\section{Kompetensi Profesional}

Hasil analisis deskriptif data penilaian kompetensi profesional (Tabel 7) memberikan informasi mengenai tingkat penguasaan kompetensi profesional dari mahasiswa calon guru yang menjadi subjek penelitian. Dari hasil analisis deskriptif tersebut diperoleh rata-rata kompetensi profesional mahasiswa calon guru matematika adalah 62,4. Hal ini menunjukkan bahwa kompetensi profesional mahasiswa calon guru matematika UNTIRTA berdasarkan kategori berada dikriteria kurang.

Tabel 8. Hasil Penilaian Kompetensi Profesional Mahasiswa Calon Guru Matematika

\begin{tabular}{cc}
\hline Deskripsi & Hasil Penilaian \\
\hline Rata-rata & 62,4 \\
Standar Deviasi & 21,7 \\
Skor Maksimum Ideal & 150,0 \\
Skor Minimum Ideal & 0,0 \\
\hline
\end{tabular}

Sementara itu, informasi mengenai penguasaan kompetensi profesional dari masing- masing mahasiswa yang dijadikan subjek penelitian dapat dilihat pada Tabel 8. Hasil analisis tes kompetensi profesional seluruh mahasiswa calon guru matematika Universitas Sultan Ageng Tirtayasa Provinsi Banten menunjukkan bahwa tidak ada satupun subjek penelitian yang mendapatkan kriteria sangat baik.

Kurangnya penguasaan kompetensi profesional mahasiswa calon guru matematika di Universitas Sultan Ageng Tirtayasa Provinsi Banten disebabkan oleh sejumlah faktor. Salah satu faktor penyebabnya adalah kurangnya praktik pembelajaran mikro (micro teaching). Hal ini mengakibatkan mahasiswa calon guru matematika hanya mempelajari satu materi matematika pada saat praktik micro teaching, sehingga penguasaan materi matematikan yang lainnya kurang. Tidak hanya itu, hasil analisis tes kompetensi profesional, menunjukkan bahwa subjek penelitian banyak sekali melakukan kesalahan. Kesalahan ini dikarenakan subjek kurang memahami konsep, kurang teliti ketika menghitung, rumus yang digunakan keliru, bahkan ada yang sama sekali tidak dijawab. Padahal materi pada soal uraian sudah dipelajari dijenjang Sekolah Menengah Pertama (SMP), Sekolah Menengah Atas (SMA), Sekolah Menengah Kejuruan (SMK) dan jenjang perguruan tinggi (perkuliahan di Jurusan Pendidikan Matematika).

Tabel 9. Hasil Tes Kompetensi Profesional

\begin{tabular}{cccc}
\hline No. & Subjek & Skor & Kriteria \\
\hline 1. & A1 & 52 & Kurang \\
2. & A2 & 96 & Baik \\
3. & A3 & 81 & Cukup \\
4. & A4 & 74 & Cukup \\
5. & A5 & 30 & Sangat Kurang \\
6. & A6 & 90 & Cukup \\
7. & A7 & 40 & Kurang \\
8. & A8 & 92 & Baik \\
9. & A9 & 35 & Kurang \\
10. & A10 & 80 & Cukup \\
11. & A11 & 51 & Kurang \\
12. & A12 & 41 & Kurang \\
13. & A13 & 60 & Kurang \\
14. & A14 & 51 & Kurang \\
15. & A15 & 49 & Kurang \\
16. & A16 & 77 & Cukup \\
\hline
\end{tabular}

Pada tes kompetensi profesional bagian 1 soal uraian nomor satu, berkaitan dengan materi peluang suatu kejadian. Materi ini sudah diajarkan di bangku Sekolah Menengah Atas (SMA) dan mata kuliah Teori Bilangan di semester empat. Soal nomor dua, berkaitan dengan bangun datar, ruang, dan sudut. Pada bangku perkuliahan, materi ini sudah diajarkan yaitu 
pada mata kuliah Geometri Ruang di semester empat. Soal nomor tiga, berkaitan dengan materi kongruensi, materi ini sudah diajarkan dimata kuliah Teori Bilangan di semester 4. Soal nomor empat, berkaitan dengan materi peluang kejadian majemuk sederhana. Materi ini telah diberikan pada mata kuliah Teori Bilangan di semester empat. Soal nomor lima yaitu turunan fungsi, materi ini diajarkan pada mata kuliah Persamaan Diferensial 1 di semester enam. Soal nomor enam yaitu materi kedudukan, jarak besar sudut, titik, garis, dan bidang dalam ruang yaitu materi yang diajarkan pada mata kuliah Geometri Ruang semester empat. Nomor tujuh berkaitan dengan materi permutasi dan kombinasi, materi ini telah diajarkan pada mata kuliah Teori Bilangan di semester empat. Berdasarkan penjelasan tersebut masih saja terdapat subjek yang menjawab salah.

Pada tes kompetensi profesional bagian 2, materi pada nomor satu berkaitan dengan kombinasi, materi ini telah diajarkan pada mata kuliah Teori Bilangan di semester empat. Materi nomor dua dan tiga, berkaitan dengan luas daerah dan volume benda putar dengan menggunakan integral. Materi ini telah diberikan pada mata kuliah Kalkulus Integral di semester dua. Materi nomor empat mengenai statistika, materi ini telah diberikan pada mata kuliah Statistika Dasar di semester empat. Materi nomor lima dan enam, berkaitan materi lingkaran, materi ini telah diberikan pada mata kuliah Geometri disemester empat. Nomor tujuh berkaitan dengan materi unsur-unsur bangun datar, keliling dan luas bangun datar, luas permukaan unsur irisan kerucut sudah diajarkan pada mata kuliah Kalkulus di semester satu. Materi nomor delapan, mengenai volum bangun ruang sisi lengkung, materi ini sudah diajarkan di Kalkulus 1 semseter satu.

Selain itu, penguasaan materi-materi perkuliahan sebelumnya juga mempengaruhi, baik mata kuliah kependidikan matematika maupun matematikanya. Sesuai dengan penelitian yang dilakukan Dewanti (2012) menyatakan bahwa Faktor yang paling mempengaruhi kesiapan mahasiswa sebagai calon pendidik profesional dibidang matematika adalah kemampuan penguasaan materi prasyarat mata kuliah PPM (micro-teaching) terutama pada mata kuliah kependidikan matematika.

\section{SIMPULAN}

Berdasarkan hasil penelitian, pembahasan, dan analisis yang telah dijelaskan, maka kesimpulan penguasaan kompetensi pedagogik dan profesional dari 16 mahasiswa Jurusan Pendidikan Matematika Universitas Sultan Ageng Tirtayasa Provinsi Banten tahun ajaran 2014/2015, yang diperoleh pada penelitian ini adalah penguasaan kompetensi pedagogik mahasiswa calon guru matematika dalam mata kuliah micro-teaching di Universitas Sultan Ageng Tirtayasa Provinsi Banten, berada pada kriteria baik. Penguasaan kompetensi profesional mahasiswa calon guru matematika dalam mata kuliah micro-teaching di Universitas Sultan Ageng Tirtayasa Provinsi Banten, berada pada kriteria kurang.

\section{DAFTAR PUSTAKA}

Arends, R. I. (2012). Learning to teach. New York: McGrawHill.

Asril, Z. (2013). Micro teaching. Jakarta: PT. Raja Grafindo Persada.

Belousa, I., \& Uzulina, S. (2012). Teacher view on social and emotional aspect of pedagogical competence. Journal of Social Sciences, 8(2),163-169.

Boyatzis, E. Richard. (2008). Competencies in the 21 st century. Journal of Management Development, 27(1). Diambil dari http://www.oostvoorncoaching.nl/wpcontent/uploads/boyatzisthe+21st+century+competencies.pdf.

Chatib, M. (2011). Gurunya manusia menjadi semua anak istimewa dan semua anak juara. Jakarta: PT. Mizan Pustaka.

Collins, J. W., \& O'Brien, N. P. (2011). Greenwood dictionary of education $\left(2^{\text {nd }}\right.$ ed.). Santa Barbara, CA: ABC-CLIO, LLC.

Dewanti, S. (2012). Analisis kesiapan mahasiswa studi pendidikan matematika sebagai calon pendidik profesional. Prosiding Seminar Nasional Pendidikan Matematika Tahun 2012. Surakarta. Diambil dari http://hdl.handle.net/1161$7 / 3275$

Fujita, H., et al (Eds.). (2004). Proceedings of the ninth international congress on mathematical education: comprehensive approach to acquiring complex facilities and projects. Boston: Kluwer Academic Publishers.

Kilic, A. (2010). Learning-centered micro teaching in teacher education. 
Internasional Journal of Instruction 3(1). Diambil dari www.e-iji.net.

Legkauskas, V., Kapalaite, A., \& Magelinskaite, S. (2014). Relationship between social competence, learning motivation, and school anxiety in primary school. Procedia-Social and Behavioral Sciences 116, 4758 - 4763. Diambil dari www.sciencedirect.com.

Michael, B. (1997). Teaching and Assessing Intercultural Communicative Competence Multilingual Matters (Series). Great Britain: Multilingual Matters.

Muijs, D., \& Reynold, D. (2011). Effective teaching: evidence and practice ( $3^{\text {rd }} \mathrm{ed}$.). London: SAGE.

Mulyasa, (2013). Uji kompetensi dan penilaian kinerja guru. Bandung: PT. Remaja Rosdakarya.

Ping, W. (2013). Micro-Teaching: A powerful tool to embedding the english teacher certification testing in the development of english teaching methodologies. International Journal of English Language and Literature Studies, 2(3), 163-175. Diambil dari http://www.aessweb.com/pdf-files/ijells2(3),163-175.pdf

Ralph, E. G. (2014). The effectiveness of microteaching: Five years' findings. International Journal of Humanities Social Sciences and Education, 1(7), 1728. Diambil dari www.arcjournals.org

Republik Indonesia. (2005a). Undang-Undang RI Nomor 14 Tahun 2005, tentang Guru dan Dosen.

Republik Indonesia. (2005b). Peraturan Pemerintah RI Nomor 19 Tahun 2005, tentang Standar Nasional Pendidikan.

Republik Indonesia. (2007). Peraturan Menteri Pendidikan Nasional Nomor 16 Tahun 2007 tentang Standar Kualifikasi Akademik dan Kompetensi Guru.

Road, A. \& Daryaganj. (2002). Dictionary of education. New Delhi: Kanishka Publishers.

Rusman. (2012). Model-model pembelajaran: Mengembangkan profesionalisme guru. Jakarta: PT. Raja Grafindo Persada.

Salirawati, D. (2011). Makalah teori micro teaching. Makalah disampaikan dalam Bimbingan Teknis Tenaga Pelatih
Konservasi dan Pemugaran, Direktorat Jenderal Sejarah dan Purbakala, Balai Konservasi Peninggalan Borobudur, di Balai Konservasi Peninggalan Borobudur. Diambil dari goo.gl/VOd2fu

Sanjaya, W. (2013). Strategi pembelajaran berorientasi standar proses pendidikan. Jakarta: Kencana.

Sasongko, H.W. (2014). Tinjauan keefektifan GI menggunakan alat peraga manipulatif dari aspek prestasi belajar bangun ruang sisi datar dan apresiasi terhadap matematika SMP. Pythagoras: Jurnal Pendidikan Matematika, 9(2), 9(2), 136-146. Diambil dari http://journal.uny.ac.id/index.php/pythagoras/article/view/9 075/pdf.

Sedgwick, F. (2008). So you want to be a teacher?. New Delhi: Sage.

Shukla, S. (2014). Teaching competency, professional commitment and job satisfaction-a study of primary school teachers. IOSR Journal of Research \& Method in Education (IOSR-JRME) 4 (3), 44-64. Diambil dari www.iosrjournals.org

Sit, M. (2012). Peningkatan kompetensi sosial anak usia dini dengan metode bermain peran. Jurnal Pendidikan Kebudayaan, 18(1). Diambil dari http://www.jurnaldikbud.net/index.php/jpnk/article/downlo $\mathrm{ad} / 72 / 69$.

Strait, J. (2006). Micro-teaching handbook for students. Hamline University Graduate School of Education Master of Arts in Teaching. Diambil dari http://www.hamline.edu/WorkArea/DownloadAsset.aspx?id=2147491080.

Sukirman, D. (2012). Pembelajaran micro teaching. Jakarta: Direktorat Jenderal Pendidikan Islam Kementrian Agama.

Syahrudin, et al. (2013). Teachers' pedagogical competence in school-based management: A case study in a public secondary school at Pare-Pare Indonesia. Journal of Education and Learning,7(4), 213-218. Diambil dari http://journal.uad.ac.id/index.php/EduLearn/article/do wnload/195/pdf_12.

Varvel, E. Virgil. (2007). Master online teacher competencies. Online Journal of Distance Learning Administration, 10(1). Diambil dari http://www.- 
Pythagoras, 12 (1), 2017 - 75

L. Linda

westga.edu/ distance/ojdla/spri-ng101/varvel101.htm.

Vijila, F., \& Sahana, A. (2015). Assesing the pedagogical competencies of affiliates $b$ school faculty members using principle component analysis. International Journal of Commerce, Business and Management (IJCBM). Diambil dari http://www.iracst.org/ijcbm/papers/vol4n o22015/22vol4no2.pdf.

Widoyoko, P.E. (2009). Evaluasi program pembelajaran panduan praktis bagi pendidik dan calon pendidik. Yogyakarta: Pusat Belajar.

Yulistiyarini, H., \& Mahmudi, A. (2015). Pengembangan perangkat pembelajaran materi geometri ruang SMP dengan memanfaatkan alat peraga manipulatif dan lingkungan. PYTHAGORAS: Jurnal Pendidikan Matematika, 10(2), 155-167. Diambil dari http://journal.uny.ac.id/index.php/pythagoras/article/view/9145/p df. 